\section{口BSERVING NATURAL}

DBJECTS: CHARACTERISTICS
DF FLDWERING PLANTS
PERCEIVED AS IMPORTANT BY
5- AND 1 D-YEAR-DLD CHILDREN

\section{Marjanca Kos, Janez Jerman}

\section{Introduction}

Living organisms make up an important part of a child's world from their early childhood. They trigger children's innate interest in them. While children make contact with nature differently than adults, little is known about how children perceive natural objects. The purpose of the research presented in this paper is to obtain a greater insight into how the observation of natural objects appears in young children.

There has been little common understanding of how the skill of observation develops in children (Johnston, 2009). According to one view, young children are considered good observers. However, during their development they begin to add more focus to their observations, 'filtering out' things they consider irrelevant because the world around them is becoming too big for them to be able to observe everything (Harlen \& Symington, 1987; Johnston, 2009, Johnston, 2011). Giving the impression that it has declined, children's observation skills indeed display U-shaped growth (Strauss, 1981) and become more sophisticated with age (Johnston, 2009). The second view is that observation is a skill we are very poor at developing effectively. A child's observational skills recede as the child develops (Johnston 2011). One of the main research problems of this study is whether and how observation skills change as children grow older.

Observation is a basic cognitive skill (Millar, 1994) and the first natural science skill a child develops (Johnston, 2011). Observation is more than just looking (Harlen, 1993; Millar, 1994; Johnston, 2011). It involves the use of all senses, recognising similarities and differences between objects, observing patterns in objects and phenomena, identifying sequences and events in the world around, and interpreting observations (Johnston, 2011). Many

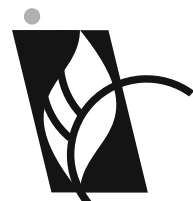

J O U R N A L

$\mathrm{O} F \bullet \mathrm{B} A \mathrm{~L} T \mathrm{I} C$

$S$ C I E N C E

E DUCATION

ISSN 1648-3898

Abstract. This research examined the ways in which children observe flowering plants, namely: which features they perceive as significant, whether the skill of observing flowering plants develops with age, and what is the difference between genders. The research involved 174 children: 89 children aged 5 and 85 children aged 10 who were given the task of choosing the plant they recognised as the same as each of the 10 given test plants among a total of 37 plants which looked more or less similar to the test plants. The analysis of the plant combinations the children most frequently mismatched showed, that colour is the feature to which they attribute the most importance. Shape turned out to be considered more important to the children than size. Older children revealed better plant observation skills than younger ones with the girls achieving better results than the boys in both age groups. The findings show that children's observation skills develop with age, and corroborate the need to support the development of observation in the educational process.

Keywords: biology education, observation skills, plant characteristics, preschool children, primary school children.

Marjanca Kos,

Janez Jerman University of Ljubljana Slovenia 
studies have confirmed that observation is a process affected by a child's past experience, ideas, expectations and interests (Brook, Driver, \& Johnston, 1989; Russell, Black, Bell, \& Daniels, 1991; Harlen, 1993; Tomkins \& Tunnicliffe, 2001; Tunnicliffe \& Litson, 2002; Eberbach \& Crowley, 2009; Johnston, 2009).

In the educational process, observation is considered to be a key skill. It is the basis of all means of collecting data (Harlen \& Qualter, 2009) and is an important component and the basis of many other skills (Macro \& McFall, 2004). Offering opportunities for observations early on can provide a firm grounding for concept development, extending knowledge (Harlen \& Symington, 1987) and better hypothesising in later phases of formal learning and researching (Tomkins \& Tunnicliffe, 2001). Observation is the starting point for biology (Tunnicliffe \& Ueckert, 2011).

Plants are an important part of the scenery of children's lives. Children notice these organisms as they walk around inside and outside (Tunnicliffe, 2001). Although some children struggle with the concept of plants being alive (Gatt et al., 2007), they mostly have an understanding of vegetation which contributes to their understanding of their environment (Tunnicliffe, 2001). Many adults have"plant blindness" - the inability to see or notice the plants in one's own environment, leading to the inability to recognise the importance of plants in both the biosphere and human affairs, and the inability to appreciate the aesthetic and unique biological features of plants (Wandersee \& Schussler, 2001). However, plants readily engage the interest of children (Tunnicliffe \& Reiss, 2000). Natural objects are attractive to children if they have aesthetic attributes (Tomkins \& Tunnicliffe, 2007), which is certainly true of most flowering plants. When observing plants, children tend to focus on striking anatomical features (Askham, 1976; Tunnicliffe \& Reiss, 2000; Tunnicliffe, 2001). When cued by adults, children attend to less obvious aspects of plants (Johnson \& Tunnicliffe, 2000). Askham (1976) showed that young children are able to classify plants. In this process, they do not use one particular method, but varied and complex strategies. In the study of plant observations and classifications, children's classifications began by identifying parts, rather than the whole. This finding indicates that children view and react to objects in their surroundings differently than adults for whom identifying whole objects is more important and is later refined to its individual segments. Adults often fail to recognise the specificity of children's observations and classifications (Askham, 1976). Among the numerous plant characteristics, colour seems to play the most important role in children's observations and classifications of plants (Askham, 1976; Johnson \& Tunnicliffe, 2000).

Another research problem in the study concerns the question of differences in observation skills between genders. Although many research studies have examined gender differences in cognitive abilities, this domain remains an area of controversy. While some authors point to gender differences in many fields including visual perception (Barkley \& Gabriel, 2007; Bear, Connors, \& Paradiso, 2007; Mann, Sasanima, Sakuma, \& Masaki, 1990), other studies show that these differences are really very small (Hyde, 1981; Ardila, Rosselli, Matute, \& Inozemtseva, 2011).

The research aimed to gain a more detailed insight into how children observe natural objects which, typically entailing a great variety and heterogeneity, strongly encourage observation. Specifically, the children participating in the research explored flowering plants that attract observers with the richness of their colours, patterns, shapes, sizes, odours and tactile characteristics. The purpose of the research presented in this paper is to determine the following:

- differences in observation between 5- and 10-year-old children, with the aim to establish how the skill of observing flowering plants changes with age;

- $\quad$ any differences between genders in their plant observations;

- the plant characteristics the children perceive as significant for distinguishing plants; and

- the characteristics of young children's observation skills by observing their behaviour and making notes of any spontaneous comments they made while they were observing the plants.

The following hypotheses were formulated:

- The skill of observing plants develops with age, older children observe better than younger children.

- There are differences between boys and girls in their plant observations.

- When observing, children attribute greater importance to certain characteristics of flowering plants than others. 


\section{Methodology of the Research}

The research design of the study was quantitative. A comparison cross-sectional analytical study was employed in which differences in plant observation were compared across two age groups and genders (Coolican, 2014).

\section{Sample of the Research}

The sampling technique used in the study was randomised two-stage cluster sampling. The study involved 174 children: 89 children aged 5 ( 49 boys and 40 girls) and 85 children aged 10 years ( 45 boys and 40 girls). The children aged 5 were attending preschool, while those aged 10 were in their fourth year of compulsory education. The preschool children had not previously been specifically involved in observing different flowering plants, although those aged 10 had been acquainted with some of the most common meadow plants as part of the "Meadow" subject in the second year of their compulsory education. Both groups of children had practised the skill of observation as part of their normal curricular activities.

\section{Ethics}

Written consent was obtained from the parents and teachers prior to conducting the research. At the beginning, the researcher orally explained the nature of the activity to the children and invited them to participate. The children were given the opportunity to refuse participation. The research was carried out in parts of the preschool or school used by all children, and in rooms the children were familiar with.

\section{Materials}

The research involved the 37 flowering plants listed in Table 1. The ten plants that were used as test plants are marked in bold.

Table 1. Plant species used in the research (the ten plants used as test plants are marked in bold).

\begin{tabular}{|c|c|}
\hline Latin name & English name \\
\hline Bellis perennis & Common daisy \\
\hline Leucanthemum ircutianum & Oxeye daisy \\
\hline Buphtalmum salicifolium & Yellow oxeye daisy \\
\hline Aposeris foetida & Odorous pig's-salad \\
\hline Taraxacum officinale & Common dandelion \\
\hline Crepis biennis & Rough hawk's beard \\
\hline Hieracium murorum & Wall hawkweed \\
\hline Tragopogon orientalis & Oriental salsify \\
\hline Symphytum tuberosum & Tuberous comfrey \\
\hline Symphytum officinale & Common comfrey \\
\hline Dentaria enneaphyllos & Drooping bittercress \\
\hline Lamium maculatum & Spotted deadnettle \\
\hline Lamium orvala & Giant deadnettle \\
\hline Galeobdolon montanum & Yellow archangel \\
\hline Ajuga reptans & Bugle \\
\hline Salvia pratensis & Meadow clary \\
\hline Salvia pratensis var. albiflora & Meadow clary (white-flowered variety) \\
\hline Orchis mascula & Early-purple orchid \\
\hline
\end{tabular}




\begin{tabular}{ll}
\hline Latin name & English name \\
\hline Glechoma hederacea & Ground-ivy \\
Echium vulgare & Viper's bugloss \\
Veronica chamaedrys & Germander speedwell \\
Myosotis sylvatica & Wood forget-me-not \\
Omphalodes verna & Blue-eyed Mary \\
Poa trivialis & Rough meadow-grass \\
Dactylis glomerata & Cock's-foot \\
Helictotrichon pubescens & Downy oat-grass \\
Alopecurus pratensis & Meadow foxtail \\
Ranunculus acris & Meadow buttercup \\
Ranunculus platanifolius & Large white buttercup \\
Caltha palustris & Marsh-marigold \\
Chelidonium majus & Greater celandine \\
Lotus corniculatus & Common bird's-foot trefoil \\
Lathyrus pratensis & Meadow vetchling \\
Lathyrus montanus & Bitter vetch \\
Anthyllis vulneraria & Common kidney vetch \\
Trifolium pratense & Red clover \\
Trifolium montanum & Mountain clover \\
\hline
\end{tabular}

In selecting the number and species of plants used in the study, the following criteria were taken into consideration: first, the selection of plants had to be large enough to enable a sufficiently wide diversity and similarity of plants with regard to their colour, shape, size and other characteristics, and at the same time not too large for preschool children to also be able to devote their full attention to it in their observation. Second, at the same time all of the selected plants needed to be simultaneously accessible during their flowering period at the time the study was being carried out (late in the month of May). Attention was paid to make sure that in no case did the plants vary only in small details. The plants belonged to different species, in most cases to different genera. Two different plant varieties were only used in plants that varied among themselves completely in colour.

Fresh whole plants without roots were used. The plants were picked daily and kept in water continuously to maintain their original features. They were picked in different locations in central Slovenia, at different heights above sea level to ensure a broad enough sample of different plant species in their flowering period at the time of the research.

\section{Procedure}

Each child was tested individually in a quiet place outside the playroom or class (in a story-telling room or library reading room). There was a low table in the room with small glass vases arranged along its outer edge, with one flowering plant in each vase (the plant names are listed in Table 1 above), each plant being clearly visible. The plants were arranged in random order. First, the researcher gave the child oral instructions on how to carry out their investigation, and checked whether the child had understood the instructions. The researcher demonstrated the procedure with the example of one plant (not one of the test plants). If necessary, the researcher repeated the instructions during the child's investigation.

First, the researcher invited the child to take a look at all of the plants in the vases on the table. Then he placed the vase with the first test plant into the child's hands. Holding the plant, the child looked at all of the plants. While doing so, he or she was allowed to move freely around the space. The child's task was to closely observe both the plant in their hands and the plants that were arranged on the table, compare them, choose that plant among those on the table they recognised as being the same as the one in their hands, and place the test plant beside the chosen 
plant on the table. The test plants were always given in the same order for each observer. The observation time was unlimited. The researcher wrote the result down. Then the researcher gave the child a vase with the plant that was next on the list of test plants, and the procedure was repeated. Each child was given 10 test plants to consider.

During the investigation the researcher did not offer any additional remarks, advice or provide encouragement. As in conducting research on such a very large sample of children we were time limited by the flowering period of the very wide range of plants, it was decided not to ask the children to explain each of their decisions. However, if a child self-initiatively expressed an opinion while investigating, the researcher wrote such spontaneous comments down. The researcher paid attention to the way the children observed the plants and also took note of the children's emotional responses.

\section{Data Analysis}

The success of accomplishing the task was measured by scoring. Children received one point for each correctly chosen plant. A maximum of 10 points could be achieved.

After verifying that the data were free from errors, matrix analyses were conducted using the Statistical Package for the Social Sciences (IBM SPSS Statistics, Version 22) software. According to the research questions and hypotheses, mainly descriptive procedures (absolute and relative frequency, mean, standard deviation) and statistical tests (two-way analysis of variance and Pearson's chi-square test) were applied. Partial eta-squared and Cramer's V were calculated as a measure of effect size (Coolican, 2014).

After analysing the plant characteristics the children had mismatched, the combinations of mismatches were classified in three groups based on plant traits. To control for assessor subjectivity in interpreting characters, two assessors were present who compared the categorisations.

\section{Results of the Research}

Overall, children of both age groups were successful in observing the plants, with the means of 8.94 correct matches (out of 10 test plants) for the older children and 6.87 for the younger ones. However, there are differences in the results among the children, both within each group as well as between the groups (Table 2).

Table 2. The means and standard deviations of the test results for correctly matched plants according to the presented group of plants by different age groups and genders (10 test plants).

\begin{tabular}{ccccc}
\hline Age & Gender & Mean & Std. Deviation & N \\
\hline \multirow{2}{*}{5 years } & Male & 6.59 & 1.383 & 49 \\
& Female & 7.20 & 1.285 & 40 \\
& Total & 6.87 & 1.367 & 89 \\
\hline \multirow{2}{*}{10 years } & Male & 8.67 & 1.279 & 45 \\
& Female & 9.25 & 1.080 & 40 \\
& Total & 8.94 & 1.218 & 85 \\
\hline \multirow{2}{*}{ Total } & Male & 7.59 & 1.687 & 94 \\
& Female & 8.23 & 1.567 & 80 \\
\hline
\end{tabular}

\section{Age Differences in the Observations}

Figure 1 shows the share of children from each age group who in completing their task achieved a certain test result. Within each age group, children varied with regard to how successful they were in completing the task. The older children were more successful in doing so than the younger children. The 10-year-olds mainly achieved $100 \%$ and $90 \%$ results, while most of the 5 -year-olds achieved $60 \%$ or $70 \%$ results. The $F$ test showed that the difference between both age groups was statistically significant $(F=114.071, p<0.05)$. The effect size was large $\left(\eta^{2}\right.$ $\geq 0.14$ ) (Table 3). 


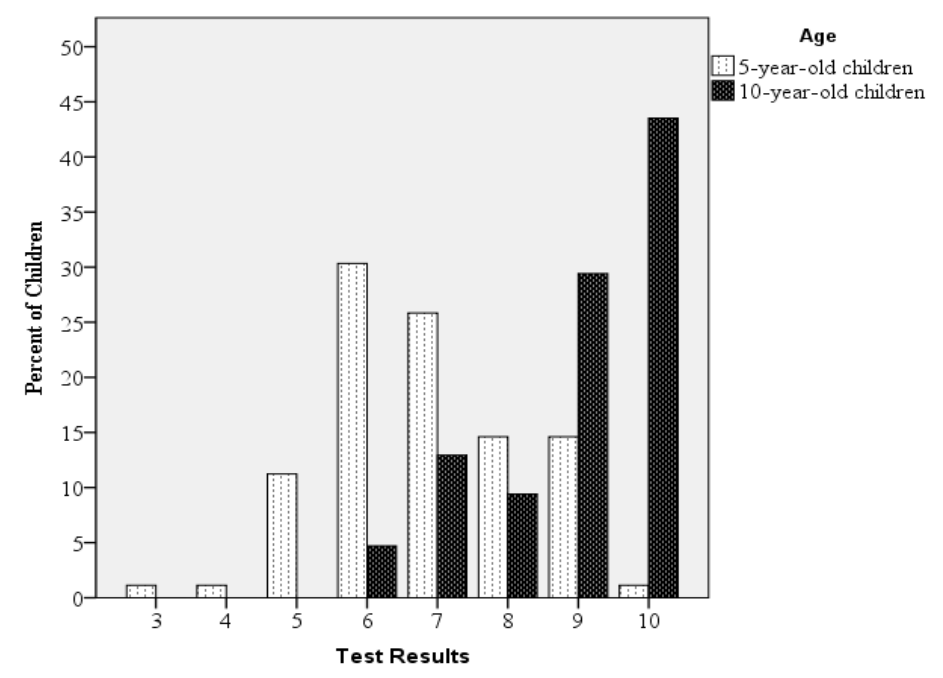

Figure 1: Bar graph of the test results for each of the two age groups.

\section{Gender Differences in the Observations}

Figure 2 shows the share of girls and boys who achieved a certain test score when completing the task. The girls were better at completing the task than the boys. This was shown in each age group. The difference was statistically significant $(F=9.518, p<0.05)$, but the effect size was small $\left(\eta^{2}<0.06\right)$ (Table 3).

There was no interaction effect of gender and age $(F=0.004, p>0.05)$ and the effect size was small $\left(\eta^{2}<\right.$ 0.06) (Table 3).

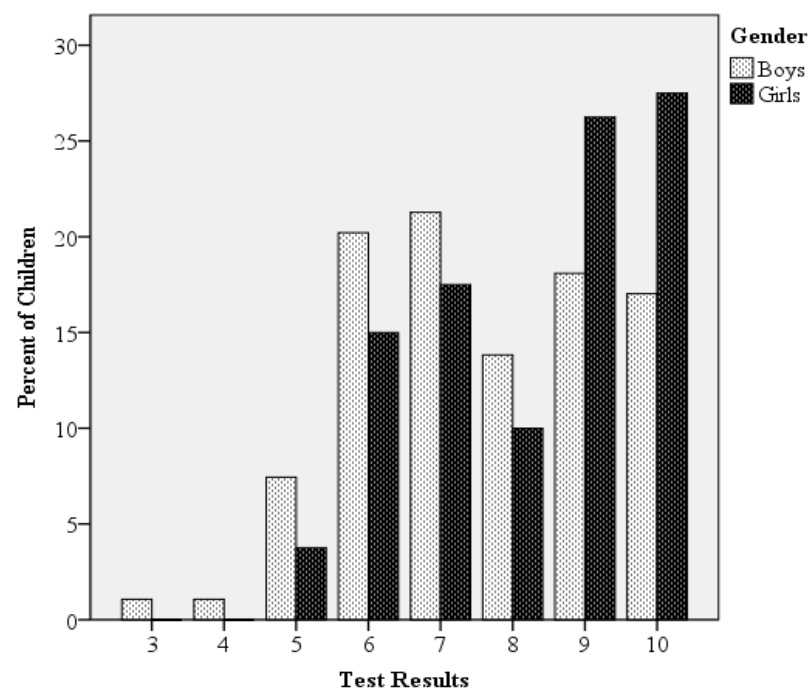

Figure 2: Bar graph of the test results for the boys and girls.

Table 3. Effect of age and genders on the test results statistically tested by the ANOVA.

\begin{tabular}{ccccc}
\hline Source & $\mathbf{F}$ & $\mathbf{d f}$ & $\mathbf{p}$ & Partial Eta Squared - $\mathbf{2}$ \\
\hline Age & 114.071 & 1 & 0.000 & 0.402 \\
Gender & 9.518 & 1 & 0.002 & 0.053 \\
Age * Gender & 0.004 & 1 & 0.949 & 0.000 \\
Error & & 170 & & \\
Corrected Total & & 173 & \\
\hline
\end{tabular}




\section{Plants Mismatched by the Children}

Table 4 shows the combinations of plants that were mistaken for another, and the percent and frequencies of children who made a certain mismatch. Pairs of plants that were mistaken for another are placed in descending order of the share of all mismatches.

Table 4. Frequencies and percent of plants that were mismatched.

(Group A includes pairs of plants that are very much alike in colour, shape, size and the position of plant parts; group B includes pairs that are very similar in colour but the differences in their shape and/or size may be estimated as medium; group C includes pairs that are very similar in colour, while their shape and/or size differences may be estimated as evident).

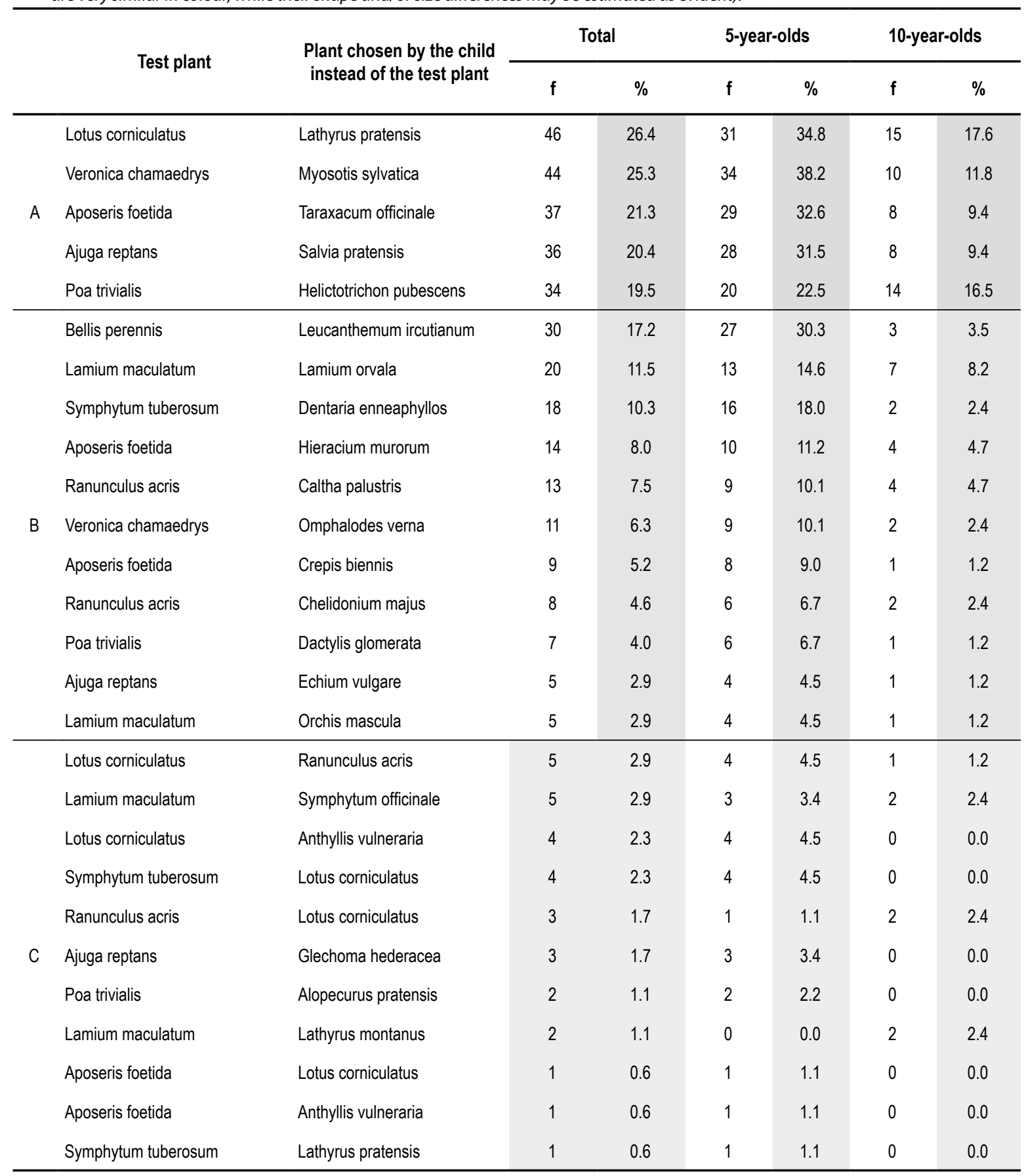


The children never mismatched plants with different flower colours, even where other characteristics of the plants were very similar.

After analysing the plant characteristics the children had mismatched, the combinations of mismatches were classified in three groups based on the plant characteristics.

The upper group (group A) contains pairs of plants most frequently mistaken for another. These pairs typically consist of two plants that are very much alike in colour, shape, size as well as the position of their flowers and other plant parts.

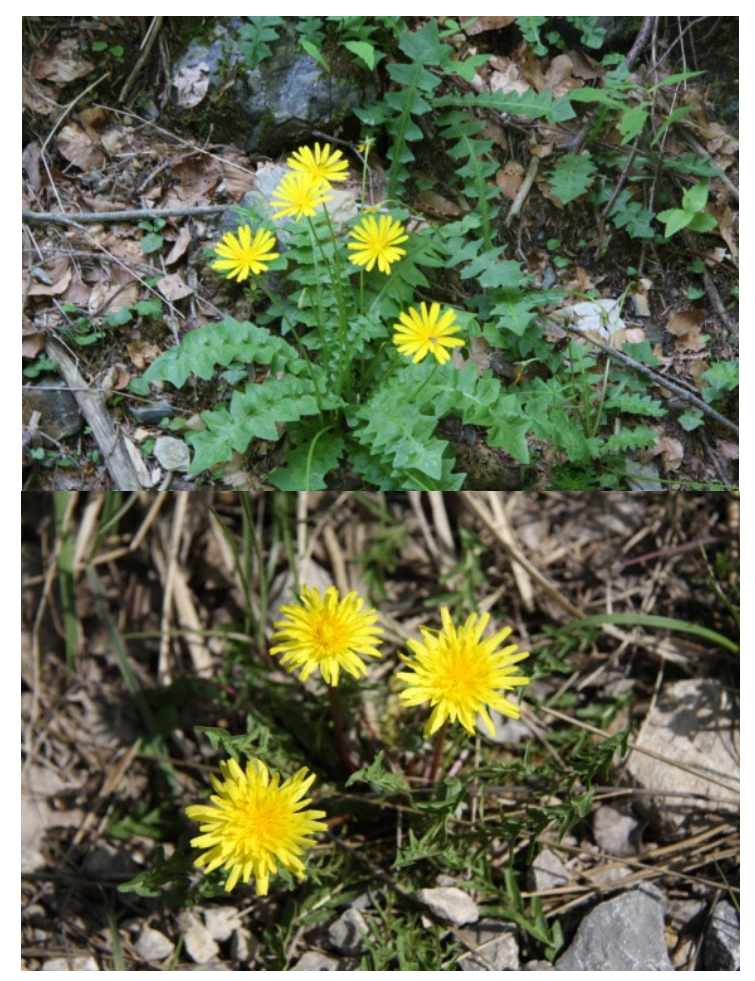

Figure 3: An example of a plant pair from group A consisting of plants the children often mistook for one another: Aposeris foetida (Odorous pig's-salad) (top) and Taraxacum officinale (Common dandelion) (bottom). Plants in this pair are typically very much alike in colour, shape, size and the placement of flowers and other plant parts.

Plants in pairs listed in the central part of the table (group B) are typically very similar to each other in colour, while the differences in their shape and/or size may be estimated as medium. Analysis of the plant characteristics in these pairs shows that the difference in their size is greater than the difference in their shape. This is the most obvious in pairs consisting of common daisy (Bellis perennis) - oxeye daisy (Leucanthemum ircutianum) and spotted deadnettle (Lamium maculatum) - giant deadnettle (Lamium orvala): these two pairs are composed of plants very similar to each other in shape and colour, but different in size. The size difference is also larger than the shape difference in the pairs of plants following next in the table: tuberous comfrey (Symphytum tuberosum) - drooping bittercress (Dentaria enneaphyllos), odorous pig's-salad (Aposeris foetida) - wall hawkweed (Hieracium murorum), meadow buttercup (Ranunculus acris) - marsh-marigold (Caltha palustris), and germander speedwell (Veronica chamaedrys) - blue-eyed Mary (Omphalodes verna).

The lower part of the table (group C) includes pairs of plants the children least often mismatched. Characteristically, these pairs consist of plants that are very similar in colour, while their shape and/or size differences may be estimated as evident.

The comparison of the structure of answers (combinations of mismatches) between the 5 - and 10-year-old children revealed no statistically significant differences between them regarding plants belonging to groups $A, B$ and $C\left(X^{2}=2.842, p>0.05\right)$. The effect size was small $(V<0.10)$. 


\section{Discussion}

The research findings are in keeping with Johnston's view (2011) that children are good observers. Up to $43 \%$ of the 10-year-olds participating in the research solved the task without error, allowing the conclusion that their plant observation skills were very accurate. The findings also indicate that observation skills develop with age. According to Johnston (2009), older children are able to engage more individually in close observations for longer periods of time, moving from broad observations to more specific ones, while younger children, as stated by Keogh and Naylor (2003), are easily distracted and may need help, support and direction to refocus.

The characteristic of the flowering plants paid most attention to by the children in their observations was colour. They never confused plants with different flower colours. It therefore seems that colour is the feature they observe the best and attribute the greatest importance to. The choice of test plants also included the meadow clary (Salvia pratensis); besides the common purple-flowered meadow clary, also the rarer white-flowered variety was provided. Although these two plants were completely similar in shape, flower size and other plant parts, and solely differed in their flower colour, not even one child mismatched these two plants. The same applies to other plant pairs that looked very similar in their shape and size of flowers and plant parts, and differed in the colour of their flowers (red clover (Trifolium pratense) - mountain clover (Trifolium montanum), meadow buttercup (Ranunculus acris) - large white buttercup (Ranunculus platanifolius) and tuberous comfrey (Symphytum tuberosum) - common comfrey (Symphytum officinale)). Colour was found by Johnson and Tunnicliffe (2000) to be the characteristic best observed by children as compared to size and shape, and the important role played by colour in children's classifications of plants was also shown by Askham (1976). Moreover, the analysis of the characteristics of the plant combinations the children mismatched, as well as the frequency of certain mismatches, showed that shape differences are better observed than size differences.

A small number of children also mismatched very different plants. For example, some children mistook spotted deadnettle (Lamium maculatum) for common comfrey (Symphytum officinale), common bird's-foot trefoil (Lotus corniculatus) for tuberous comfrey (Symphytum tuberosum) or common bird's-foot trefoil for odorous pig's-salad (Aposeris foetida) - these plants would be recognised by most adults as manifestly different from each another.

The technique used by many 5 -year-olds when looking for a suitable match for the test plant was that, holding the test plant in their hands, they 'skipped over' the available plants, and focused more closely only on plants whose flowers were the same colour as those of the test plant. This allows the conclusion that they picked the flower colour as the main variable, and paid attention to other variables only in the next observation phase. This raises the assumption that they were only able to focus on a single variable at a time. To a smaller extent, this way of observing was also noticed in the 10-year-olds. According to Piaget's theory of cognitive development, 5-year-old children are in their preoperational stage. In this stage, children limit themselves to one dimension in their observations and inferences, neglecting others, whereas 10-year-old children have already entered the concrete operational stage. Children in this developmental stage are capable of keeping two or more variables in their mind at the same time (Labinowicz, 2010).

The characteristics of the flowers were regarded as the most important by the children, and only in rare cases did they also observe the leaves and stems more closely. It was evident in their observations that they paid greatest attention to obvious parts of the plants. Askham (1976) showed that young children are able to classify plants using varied and complex strategies in which the stimulation value of particular plant parts is important. The presence of obvious characteristics increases a child's interest in a certain plant (Tunnicliffe \& Reiss, 2000; Tunnicliffe, 2001).

The task the children were asked to perform required close observation of differences in details since many plants included in the research looked similar. A large majority of children's observations concern gross features rather than more detailed ones. While children are capable of seeing details, they often fail to notice them unless asked to pay attention to them. The value of observing details as opposed to only more global features is that it often helps in making sense of other observations and improves the identification of similarities and differences in grouping objects (Harlen \& Symington, 1987).

Another important point is that observation is affected by preconceived ideas (Brook, Driver, \& Johnston, 1989; Russell et al., 1991; Tomkins \& Tunnicliffe, 2001; Tunnicliffe \& Litson, 2002; Eberbarch \& Crowley, 2009; Johnston, 2009). The conceptual framework of a child influences how they make and interpret observations. Children's concepts contribute to them focusing their attention on what to observe (i.e. what they perceive as 
significant) and those concepts 'structure' their way of making sense of the data collected (Russell et al., 1991). The study also indicates the influence of past concepts and experiences on observation. Some of the plants were very common, 'common flowers' such as wood forget-me-not (Myosotis sylvatica), common dandelion (Taraxacum officinale), common daisy (Bellis perennis) and oxeye daisy (Leucanthemum ircutianum), suggesting that even the young children had previous experience with them. In some cases, when a child received the test plant the following response was observed: after being given e.g. germander speedwell (Veronica chamaedrys) which is similar to forget-me-not, they would comment contentedly: "Aha, the forget-me-not. I know this one". Then the child observed the plants and finally placed the test plant next to the forget-me-not. The child's cognitive structure led her or him to observe 'through the lens' of their own cognitive constructs only to arrive at the wrong solution. Similar responses were noticed for all other 'common' plants which are assumed to be very well known to young and older children.

The girls participating in the study performed better than the boys, with the differences being statistically significant. This result was established in each age group. It supports the idea of gender differences in visual perception (Barkley \& Gabriel, 2007; Bear, Connors, \& Paradiso, 2007; Mann et al., 1990). Given that observation is also affected by interests and preconceptions, the findings of Dawson (1983), Wandersee \& Schussler (1999), Gatt et al. (2007) and Lückmann and Menzel (2014) stating that girls prefer plants, are more interested in learning about them or know more about them than boys, could be relevant.

When observing the children's behaviour in the study, it was found that the 5-year-old children used more senses in their observations than the 10-year-olds. The younger children very often touched and smelled the plants (so extra care was taken to provide a sufficient number of fresh plant specimens since they needed to be replaced after being touched all over by a certain number of children). This way of observing was noticed much less often in the 10-year-olds. Johnston's study (2009) also showed that young children's initial observations are tactile, and that they also use senses other than sight to the same extent.

Natural objects are very appropriate for observation. Heterogeneous natural materials trigger rich impulses which stimulate all of a child's senses, and their observations and explorations. Such objects include flowering plants. The study included very diverse flowering plants that varied among themselves in several features: colour, shape, size, the position, scent, tactile characteristics of the flowers, leaves and stems. While it is common knowledge that children are more attracted to animals than plants (Wandersee, 1986; Schussler \& Ozak, 2008), they can generally be considered to be interested in flowering plants, describing them as 'beautiful'. Tomkins and Tunnicliffe's study (2007) showed that aesthetic attributes are among the important factors that make natural objects attractive to children. When entering the research room and seeing the flowers, many of the children in the research reported here expressed spontaneous affective remarks such as "Wow!", "How beautifu!!", or "How many there are!". The children's observations clearly included an affective component which may also be defined as wonder and aesthetic appreciation - an important area of early years learning in both 'science' and other developmental domains.

The observation of natural objects has a motivational value and positive effect on attitude, knowledge, language and communication skills (Tomkins \& Tunnicliffe, 2007). Play and learning in a natural environment, which is an infinite source of natural objects and materials, stimulate observations and a sense of wonder in children (Wilson, 2008; Maynard \& Waters, 2007). Moreover, the findings of neuroscience show that the human brain has evolved to code natural images (Graham \& Field, 2007; Yantis, 2014). At a time when many Western countries perceive that fewer opportunities are being offered to preschool children for outdoor play (Clements, 2004; Palmer, 2006; Waller, Sandseter, Wyver, Ärlemalm-Hagsér, \& Maynard, 2010), being aware of the importance of children's contact with the natural environment, materials and objects is crucial.

\section{Conclusions and Implications}

The results of the present study lead to three main conclusions. The first is that older children revealed better observation of flowering plants than younger ones, indicating that observation is a skill that develops with age. Next, girls performed better than boys, suggesting gender differences in observation skills when looking at plants. Third, when observing the plants the children attributed different importance to various variables: colour was the feature the children give most importance to, and shape turned out to be considered more important than size. 
The results of this study hold some important educational implications. The finding that observation can be developed with age suggests that observation should be encouraged in the educational process. Its successful development depends on how many opportunities for different kinds of observation children are offered. When observing natural materials, children should be encouraged to observe the details and numerous variables, while taking into account that children pay most attention to obvious, conspicuous features, lay a strong emphasis on colour, and notice the differences in shape better than the differences in size. These findings could be taken into account in the preparation of study literature, such as identification keys adjusted to children.

\section{References}

Ardila, A., Rosselli, M., Matute, E., \& Inozemtseva, O. (2011). Gender differences in cognitive development. Developmental Psychology, $47(4), 984-990$.

Askham, L. A. (1976). The effects of plants on classification behavior in an outdoor environment. Journal of Research in Science Teaching, $13(1), 49-54$.

Barkley, C. L., \& Gabriel, K. I. (2007). Sex differences in cue perception in a visual scene: Investigation of cue type. Behavioral Neuroscience, 121 (2), 291-300.

Bear, M. F., Connors, B. W., \& Paradiso, M. A. (2007). Neuroscience: Exploring the brain. Baltimore: Lippincott Williams \& Wilkins.

Brook, A., Driver, R., \& Johnston, K. (1989). Learning processes in science: a classroom perspective. In J. Wellington (Ed.), Skills and processes in science education. A critical analysis (pp. 63-82). London: Routledge.

Clements, R. (2004). An investigation of the status of outdoor play. Contemporary Issues in Early Childhood 5 (1), 68-80.

Coolican, H. (2014). Research methods and statistics in psychology. Hove: Psychology Press.

Dawson, C. J. (1983). What science do students prefer? A study of some south Australian twelve year olds. School Science Review, 65, 133-136.

Eberbach, C., \& Crowley, K. (2009). From everyday to scientific observation: How children learn to observe the biologist's world. Review of Educational Research, 79 (1), 39-68.

Gatt, S., Tunnicliffe, S. D., Kurtsten, B., \& Lautier, K. (2007). Young Maltese children's ideas about plants. Journal of Biological Education, 41 (3), 117-121.

Graham, D. J., \& Field, D. J. (2008). Natural images: Coding efficiency. In L. R. Squire (Ed.), Encyclopedia of Neuroscience (pp. 19-27). Oxford: Academic Press.

Harlen, W. (1993). Teaching and learning primary science. London: Paul Chapman Publishing.

Harlen, W., \& Symington, D. (1987). Helping children to observe. In W. Harlen (Ed.), Primary science: Taking the plunge (pp. 21-35). London: Heinemann.

Harlen, W., \& Qualter, A. (2009). The teaching of science in primary schools. Abingdon: Routledge.

Hyde, J. S. (1981). How large are cognitive gender differences? A meta-analysis using $\omega-2$ and d. American Psychologist, 36 (8), 892-901.

Johnson, S., \& Tunnicliffe, S. D. (2000). Primary children talk about plants in the garden. Paper presented at the NARST Annual International Conference, New Orleans, USA.

Johnston, J. S. (2009). What does the skill of observation look like in young children? International Journal of Science Education, 31 (18), 2511-2525.

Johnston, J. (2011). Early explorations in science. Maidenhead: Open University Press.

Keogh, B., \& Naylor, S. (2003). Do as I do: Being a role model in the early years. Primary Science Review, 78, 7-9.

Labinowicz, E. 2010. Izvirni Piaget [The Piaget Primer]. Ljubljana: DZS.

Lückmann, K., \& Menzel, S. (2014). Herbs versus trees: Influences on teenagers' knowledge of plant species. Journal of Biological Education, 48 (2), 80-90.

Mann, V. A., Sasanuma, S, Sakuma, N., \& Masaki, S. (1990). Sex differences in cognitive abilities: A cross-cultural perspective. Neuropsychologia, 28 (10), 1063-1077.

Millar, R. (1994). What is "scientific method" and can it be taught? In R. Levinson (Ed.), Teaching Science (pp. 164-177). London: Routledge.

Macro, C., \& Mc Fall, D. (2004). Questions and questioning: Working with young children. Primary Science Review, 83, 4-6.

Maynard, T., \& Waters, J. (2007). Learning in the outdoor environment: a missed opportunity? Early Years, 27 (3), 255-265.

Palmer, S. (2006). Toxic childhood: How the modern world is damaging our children and what can we do about it. London: Orion Books.

Russell, A., Black, P., Bell, J., \& Daniels, S. (1991). Assessment matters no. 8, Observation in school science. London: School Examinations and Assessment Council.

Schussler, E. E., \& Olzak, L. A. (2008). It's not easy being green: Student recall of plant and animal images. Journal of Biological Education, 42 (3), 112-118.

Strauss, S. (1981). U-shaped behavioural growth. New York: Academic Press.

Tomkins, S. P., \& Tunnicliffe, S. D. (2001). Looking for ideas: Observation, interpretation and hypothesis-making by 12-year-old pupils undertaking science investigations. International Journal of Science Education, 23 (8), 791-813.

Tomkins, S., \& Tunnicliffe, S. D. (2007). Nature tables: Stimulating children's interest in natural objects. Journal of Biological Education 41 (4), 150-155. 
Tunnicliffe, S. D. (2001). Talking about plants - Comments of primary school groups looking at plants as exhibits in a botanical garden, Journal of Biological Education, 36 (1), 27-34.

Tunnicliffe, S. D., \& Reiss, M. J. (2000). Building a model of the environment: How do children see plants? Journal of Biological Education, 34 (4), 172-177.

Tunnicliffe, S. D., \& Litson, S. (2002). Observation or imagination? Primary Science Review 71, 25-27.

Tunnicliffe, S. D., \& Ueckert, C. (2011). Early biology: the critical years for learning. Journal of Biological Education, 45 (4), $173-$ 175.

Waller, T., Sandseter, E. B. H., Wyver, S., Ärlemalm-Hagsér, E., \& Maynard, T. (2010). The dynamics of early childhood spaces: Opportunities for outdoor play? European Early Childhood Research Journal 8 (4), 437-443.

Wandersee, J. H. (1986). Plants or animals - which do junior high school students prefer to study? Journal of Research in Science Teaching, 23, 415-426.

Wandersee, J. H., \& Schussler, E. E. (1999). Preventing plant blindness. The American Biology Teacher, 61 (2), 82-86.

Wandersee, J. H., \& Schussler., E. E. (2001). Toward a theory of plant blindness. Plant Science Bulletin, 17, 2-9.

Wilson, R. (2008). Nature and young children: Encouraging creative play and learning in natural environments. Abingdon: Routledge.

Yantis, S. (2014). Sensation and perception. New York: Worth Publisher.

\section{Marjanca Kos \\ (Corresponding author)}

Janez Jerman
Ph.D., Senior Lecturer, Faculty of Education, University of Ljubljana, Kardeljeva ploščad 16, SI-1000 Ljubljana, Slovenia.

E-mail:marjanca.kos@guest.arnes.si Website: http://www.pef.uni-lj.si/

Ph.D., Associate Professor, Faculty of Education, University of Ljubljana, Kardeljeva ploščad 16, SI-1000 Ljubljana, Slovenia. E-mail: janez.jerman@pef.uni-lj.si Website: http://www.pef.uni-lj.si/ 